\title{
Histologic evaluation of the effect of nicotine administration on bone regeneration. A study in dogs
}

\section{Avaliação histológica do efeito da nicotina sobre a regeneração óssea. Estudo em cães}

\author{
Juliana Bezerra Saldanha* \\ Suzana Peres Pimente1* \\ Marcio Zaffalon Casati** \\ Antonio Wilson Sallum*** \\ Enilson Antonio Sallum $* * *$ \\ Francisco Humberto Nociti Júnior****
}

\begin{abstract}
The objective of this study was to investigate the histometric impact of nicotine on bone regeneration of surgically created alveolar ridge defects in dogs. Sixteen mongrel dogs were used. One defect was surgically created unilaterally in the mandible, and left to heal spontaneously. The animals were randomly assigned to one of the following groups: Group 1 - control $(\mathrm{n}=8)$ and Group 2 - subcutaneous nicotine administration $(2 \mathrm{mg} / \mathrm{kg})$ twice a day $(\mathrm{n}=8)$. After 4 months, the animals were sacrificed and the specimens routinely processed for semi-serial decalcified sections. Bone height (BH), bone width (BW), bone density (BD), and bone area (BA) of the newly-formed bone were evaluated. Intergroup analysis (Mann-Whitney rank sum test) showed that regardless of the presence of nicotine, no significant differences were observed regarding bone width (BW), bone area (BA) and bone height $(\mathrm{BH})(\mathrm{p}>0.05)$. On the other hand, it was demonstrated that nicotine administration significantly influenced the proportion of mineralized tissue within the limits of the newly-formed bone (BD) $(p<0.001)$. Within the limits of the present study, it can be concluded that nicotine might affect but not prevent bone healing in defects left to heal spontaneously.
\end{abstract}

DESCRIPTORS: Smoking; Nicotine; Tobacco; Bone regeneration.

\begin{abstract}
RESUMO: O objetivo do presente estudo foi avaliar histometricamente a influência da nicotina sobre a regeneração óssea de defeitos criados cirurgicamente em rebordos alveolares edêntulos de cães. Defeitos ósseos foram criados cirurgicamente em um dos lados da mandíbula de dezesseis cães e foram deixados para que curassem espontaneamente. Os animais foram aleatoriamente designados para um dos seguintes grupos: Grupo $1-\operatorname{controle}(n=8)$ e Grupo 2 - administração subcutânea de nicotina $(2 \mathrm{mg} / \mathrm{kg})$ duas vezes ao dia durante 4 meses $(\mathrm{n}=8)$. Os animais foram sacrificados, e secções semi-seriadas descalcificadas, obtidas. Os parâmetros histométricos avaliados foram altura, largura, área e densidade do tecido ósseo neoformado. A análise intergrupos (Mann-Whitney "rank sum test") demonstrou que a administração de nicotina não influenciou altura, largura e área de tecido ósseo neoformado $(p>0,05)$. Entretanto, a administração de nicotina influenciou significativamente a densidade do tecido ósseo neoformado $(\mathrm{p}<0,001)$. Dentro dos limites do presente estudo, pode-se concluir que a nicotina pode afetar, mas não impedir a regeneração de defeitos ósseos criados cirurgicamente em mandíbulas edêntulas de cães.
\end{abstract}

DESCRITORES: Tabagismo; Nicotina; Tabaco; Regeneração óssea.

\section{INTRODUCTION}

Smoking has an adverse effect on bone in general. Post-menopausal women who smoke lose significantly more cortical bone, and have more spinal osteoporosis than nonsmoking counterparts ${ }^{14}$. Cigarette smoking may increase bone resorption at fracture ends ${ }^{5,10}$ and interfere with osteoblastic function ${ }^{1,16}$. A 15-patient clinical study revealed that $80 \%$ of the individuals with impaired osseous healing were smokers ${ }^{9}$. Studies with twins discordant for cigarette consumption demonstrated accelerated bone turnover and significant reductions in bone mineral density among the smoking twins $^{6}$. These physiologic responses to smoking may be caused by nicotine, which is the major constituent of the particulate phase of tobacco and its most cytotoxic and vasoactive substance.

\footnotetext{
*PhD Students; **Associate Professor; ***Professors; ****Assistant Professor - Department of Prosthodontics and Periodontics, Division of Periodontics, School of Dentistry of Piracicaba, State University of Campinas.
} 
Saldanha JB, Pimentel SP, Casati MZ, Sallum AW, Sallum EA, Nociti Júnior FH. Histologic evaluation of the effect of nicotine administration on bone regeneration. A study in dogs. Braz Oral Res 2004;18(4):345-9.

Nicotine in tobacco products causes peripheral vasoconstriction and tissue ischemia and decreases oxygen tension ${ }^{4}$. Moreover, nicotine depresses osteoblast activity, may inhibit revascularization of bone grafts ${ }^{1}$, has a negative impact on bone healing $^{4}$, and inhibits the expression of a wide range of cytokines including those associated with neovascularization and osteoblast differentiation ${ }^{20}$. Therefore, the present study aimed to investigate the impact of nicotine on the regeneration of surgically created alveolar bone defects in dogs.

\section{MATERIALS AND METHODS Animals}

Sixteen mongrel dogs in good health were used (approximately $15 \mathrm{~kg}$ of body weight -2 years old). The animals were kept in individual cages with access to food and water ad libitum. Prior to the surgical procedures, all animals were allowed to acclimatize to the facility environment for a period of 7 days. The protocol was approved by the University of Campinas Institutional Animal Care and Use Committee.

\section{Surgical procedures}

Oral prophylaxis was performed 2 weeks prior to tooth extraction and again 2 weeks prior to the creation of the bone defects. The animals received $1.5 \mathrm{ml} / 10 \mathrm{~kg}$ of acepromazine (Fortdodge, Campinas, SP, Brazil) followed by intravenous injection of $25 \%$ sodium thiopental solution (Cristália, Itapira, $\mathrm{SP}$, Brazil) $(0.5 \mathrm{ml} / \mathrm{kg})$ and local administration of $\%$ xylocaine (Merrel Lepetit, Santo Amaro, SP, Brazil) (1:50,000 epinephrine) for all surgical procedures. At the beginning of the experiment, the first, second and third lower molars were removed unilaterally, creating an edentulous area in the posterior region of the lower jaw. After 3 months of healing, full-thickness midcrest incisions were utilized following which full thickness flaps were elevated bucally and lingually to expose the edentulous alveolar ridge. Osseous saddle-type defects measuring approximately $12 \mathrm{~mm} \times 8 \mathrm{~mm}$ were prepared in the edentulous alveolar molar area of the mandible by removing the buccal and lingual plates and associated cancellous bone (Figure 1), utilizing surgical rotary and hand instruments under profuse saline irrigation. The exposed bone surfaces were planed to smooth the margins of the defect. An attempt was made to make the defects uniform; however, due to variations in the basal width of the ridge, exact standardization was not

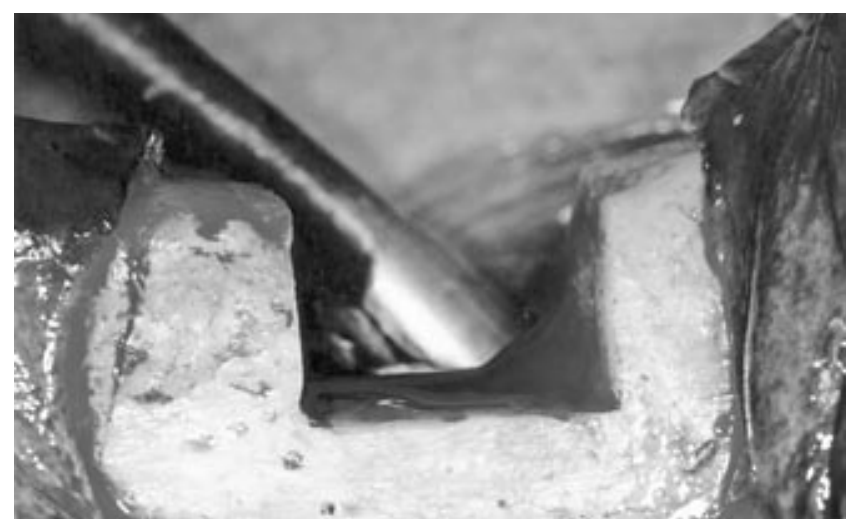

FIGURE 1 - Clinical appearance of the surgically created bone defect.

possible. The actual dimensions of each osseous defect were measured with a periodontal probe and recorded. Subsequently, primary wound closure was achieved with vertical mattress and interrupted e-PTFE sutures (Gore-Tex ${ }^{\circledR}$ Suture, CV-5, WL Gore and Associates, Inc., Flagstaff, AZ, USA). A prophylactic antibiotic treatment (Pentabiótico ${ }^{\circledR}$, Wyeth-Whitehall Ltda., São Paulo, SP, Brazil) was initiated the day before the creation of the defects, and continued for 7 days postoperatively. Oral prophylaxis consisting of supragingival scaling was performed every 2 weeks. Chlorhexidine rinse was used daily during the whole experimental phase and the dogs were maintained on a soft diet. Sutures were removed 10 days after surgery. The defects were left to heal spontaneously during four months. One day after the surgical procedures for the creation of the defects, eight dogs were randomly assigned to receive subcutaneous nicotine administration (Sigma, St. Louis, MO, USA) for the whole experimental period. A total dose of $4 \mathrm{mg} / \mathrm{kg} /$ day was used, and given twice a day in a twelve-hour interval ( $2 \mathrm{mg} / \mathrm{kg}$ each time).

\section{Nicotine and cotinine serum levels: analytical methods}

Blood samples were taken hourly from $15 \mathrm{~min}$ utes to 8 hours after the first injection of the day on the first and last days of nicotine administration. Serum samples were assayed for concentrations of nicotine and cotinine by high-pressure liquid chromatography, composed of two pumps (LC10ADvp, Shimadzu Corporation, Tokyo, Japan), programmed by a system controller (SCL-10ADvp, Shimadzu Corporation, Tokyo, Japan), a UV-Vis detector (SPD-10ADvp, Shimadzu Corporation, Tokyo, Japan) set at $260 \mathrm{~nm}$ and a reversed-phase 
Saldanha JB, Pimentel SP, Casati MZ, Sallum AW, Sallum EA, Nociti Júnior FH. Histologic evaluation of the effect of nicotine administration on bone regeneration. A study in dogs. Braz Oral Res 2004;18(4):345-9.

column Luna (Column Luna, Phenomenex, USA $150 \mathrm{~mm} \times 4.6 \mathrm{~mm}$ I.D. X $5 \mu \mathrm{m})$. The mobile phase consisted of $20 \mathrm{mM}$ dibasic potassium phosphate, $20 \mathrm{mM}$ monobasic potassium phosphate containing $0.1 \%$ triethylamine. The $\mathrm{pH}$ of the solution was adjusted to 6.3 with phosphoric acid and acetonitrile $(10 \%)$ was added to the final solution. The flow rate was $1.0 \mathrm{ml} / \mathrm{min}$. 2-Phenylimidazole (Sigma, St. Louis, MO, USA) was used as an internal standard. All the reagents used to perform the method were HPLC grade. The extraction of the samples followed the methodology previously described by Nakajima et al. ${ }^{11}$ (2000); however, they were dried under nitrogen at room temperature. The injection volume was $20 \mu \mathrm{l}$ and the limit of quantification was $10 \mathrm{ng} / \mathrm{ml}$.

\section{Histometric procedure}

The animals were sacrificed 4 months after the defect creation by induction of deep anesthesia with subsequent intravenous sodium pentobarbital overdose. The jaws were removed and fixed in $4 \%$ neutral formalin for $48 \mathrm{~h}$. The specimens were demineralized in a solution of equal parts of $50 \%$ formic acid and 20\% sodium citrate for 90 days. Paraffin semi-serial sections $(6 \mu \mathrm{m})$ were obtained in a bucco-lingual direction and stained with hematoxylin and eosin, and Masson's trichrome. Using an image analysis system (Image-Pro ${ }^{\circledR}$, Media Cybernetics, Silver Spring, MD, USA), the following parameters were obtained for the newly-formed bone by a calibrated examiner: bone height $(\mathrm{BH})$, bone width (BW), bone density (BD), and bone area (BA). BW was evaluated in three different portions of the defect: (a) apical (the closest to the base of the defect), (b) intermediate, and (c) coronal. Measurements of bone density and bone area were carried out by point counting. From the point counts, the area $\left(\mathrm{mm}^{2}\right)$ and the relative concentration of mineralized tissue (\%) within the total bone area were calculated. The distance between the points was known, and this allowed the conversion of point numbers to $\mathrm{mm}^{2}$. The total bone area served as reference. Measurements were averaged to allow intergroup and intragroup analysis.

\section{Statistical analysis}

The hypothesis that there was no difference between the groups (with or without nicotine) regarding the evaluated parameters was tested by intergroup analysis using the Mann-Whitney test $($ alpha $=0.05)$. In addition, intragroup analysis was performed to test the hypothesis that there was no difference in BW regarding the apical, intermediate and coronal measurements.

\section{RESULTS}

\section{Serum levels of nicotine and cotinine}

Over time follow-up of nicotine and cotinine serum levels demonstrated a similar pattern during the first and last days of nicotine administration. The highest serum level of nicotine was noted 15 minutes after its administration, and a time-dependent decrease was observed. A significant decrease in the serum level of nicotine was observed 1 hour after its administration with a tendency for stabilization after the third hour. The highest value of cotinine serum levels was observed 1 hour after nicotine administration, and a tendency to stabilize was then noted after the fourth hour. Interestingly, on the first day of nicotine administration, nicotine/cotinine serum levels were slightly higher than on the last day of administration. However, for both periods, similar values were obtained.

\section{Histometric analysis}

Statistical analysis showed that, regardless of the presence of nicotine, no significant differences were observed for BW in any of the portions evaluated, i.e., apical, intermediate or coronal ( $p>0.05$ ). In addition, the administration of nicotine did not result in a significant difference for $\mathrm{BH}$ and $\mathrm{BA}$. In contrast, intergroup analysis demonstrated that nicotine administration significantly influenced the proportion of mineralized tissue within the limits of the newly-formed bone (BD) $(\mathrm{p}<0.001)$ (Graph 1).

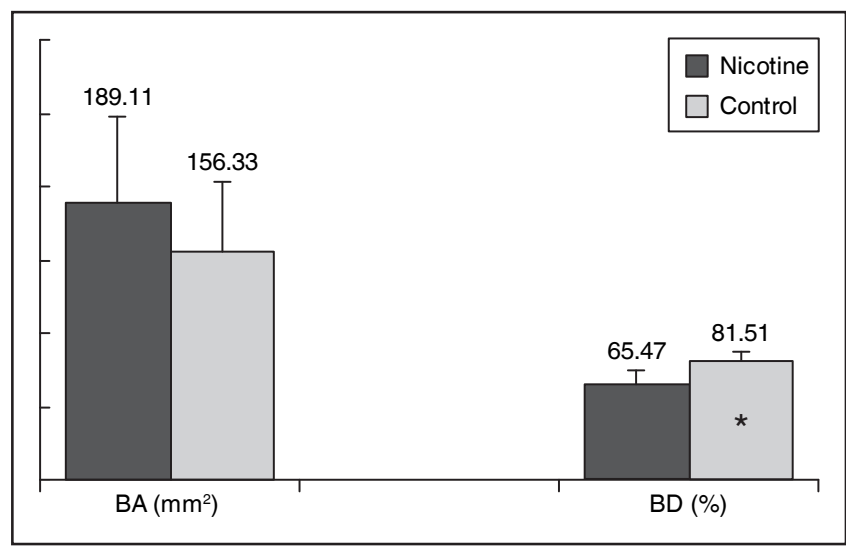

GRAPH 1 - Bar graph showing the average and standard deviation for bone density (BD) and bone area (BA) of the newly-formed bone $\left({ }^{*} \mathrm{p}<0.05\right)$. 
Saldanha JB, Pimentel SP, Casati MZ, Sallum AW, Sallum EA, Nociti Júnior FH. Histologic evaluation of the effect of nicotine administration on bone regeneration. A study in dogs. Braz Oral Res 2004;18(4):345-9.

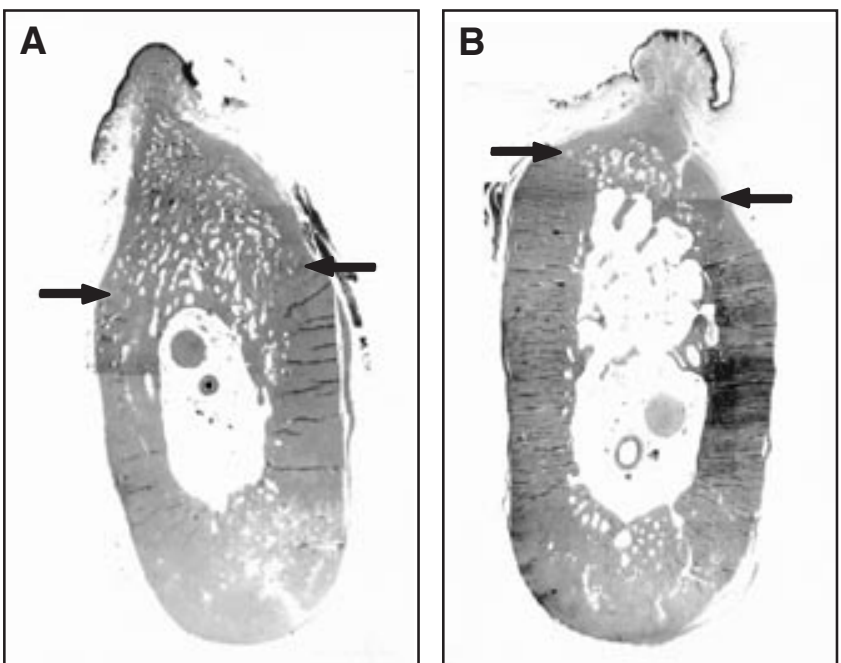

FIGURE 2 - Sections illustrating the histological findings for both the control (A) and test $(\mathbf{B})$ groups. Note that nicotine administration resulted in less dense bone in the test group than in the non-treated group. The arrows identify the limit between preexisting and new bone. (H. E.; $3.75 \mathrm{X}$ ).

Figures 2A and 2B illustrate the histological findings for the control and test groups, respectively.

\section{DISCUSSION AND CONCLUSION}

This study evaluated the impact of nicotine on the regeneration of surgically created alveolar bone defects in dogs. The results demonstrated incomplete bone regeneration and a persisting defect within the time period of investigation. The regeneration of all defects was limited to the formation of a cap that sealed the surgically created openings of the marrow space as previously reported ${ }^{17,18}$. However, nicotine administration resulted in significantly lower BD in the test group compared with the control group.

The main pharmacological action of nicotine is the activation of the sympathetic nervous system. Nicotine also acts directly on the small vessels producing vasoconstriction, systemic venoconstriction and increasing coronary vascular resistance ${ }^{7,15}$. Therefore, blood supply is primarily affected by nicotine. A literature review demonstrates the inherent capacity of bone to regenerate due to local cells and signaling molecules. When osseous healing exhausts the localized supply of cells and signaling molecules, renewal is contingent upon vascularity and operational activity of endogenous cells activated during the early phase of bone repair $^{4}$. Nicotine's effect was seen early in the healing process, during the inflammatory stage. Nicotine is known to be a potent antiinflamatory and immunosuppressive agent ${ }^{19}$. If the initial inflammatory response triggering the bone healing cascade were suppressed, the expression of subsequent cytokines would be diminished. The intense vasoconstrictive effect that nicotine exerts on the microvasculature may inhibit the angioblastic response during revascularization in the healing area, and decrease osteoblast activity. The fact that, in the present study, nicotine promoted lower BD is in agreement with previous observations of inhibition of revascularization of bone grafts ${ }^{1}$, lowered healing in parietal bone defect ${ }^{4}$, and inhibition of genes directly related to neovascularization and osteoblast differentiation. Therefore, the effects of nicotine appear to involve more than just local vasoconstriction ${ }^{20}$. Moreover, in vitro studies support the concept that nicotine exerts a deleterious effect on bone metabolism. The following have been demonstrated in the presence of nicotine ${ }^{3}$ : dose-dependent inhibition of proliferation, extracellular matrix production and attachment of human gingival fibroblasts, in addition to increased collagenase activity ${ }^{12,21}$, dose-dependent inhibition of attachment, chemotaxis of periodontal ligament fibroblasts and activity of alkaline phosphatase. Because increased alkaline phosphatase (ALPase) activity precedes bone mineral deposition and inhibition of ALPase has been related to decreased bone mineralization, it can be speculated that nicotine may impede mineral deposition of bone ${ }^{13}$. The direct effect of nicotine on osteoblast-like cell activity in vitro is contradictory, and cannot be used to support or refute the present findings. Fang et $a .^{2}$ (1991) found that nicotine suppressed DNA synthesis and cell proliferation and stimulated alkaline phosphatase synthesis in osteoblast-like UMR106-01 rat osteosarcoma cells. Ramp et al. ${ }^{13}$ (1991), on the other hand, showed that nicotine stimulated DNA synthesis, and inhibited collagen and ALPase synthesis in chick calvarial osteoblastlike cells. The disparity among the in vitro data may be related to the cell type or cell culture conditions. Probably, the best experimental evidence for the negative effect of nicotine on bone derives from studies of bone metabolism following injury. In the rabbit fracture healing model, several investigators have found that bone graft vascularization and subsequent bone formation is reduced with nicotine treatment ${ }^{8}$. In the present study, the lack of significant differences regarding the other parameters investigated (BA, BW, $\mathrm{BH}$ ) may in part be due to the random sampling variability. Therefore, 
Saldanha JB, Pimentel SP, Casati MZ, Sallum AW, Sallum EA, Nociti Júnior FH. Histologic evaluation of the effect of nicotine administration on bone regeneration. A study in dogs. Braz Oral Res 2004;18(4):345-9.

an increased number of animals could possibly have rendered statistical significance.

Within the limits of the author's knowledge, there is very limited information on nicotine/cotinine serum levels after subcutaneous nicotine administration in dogs. Therefore, in the present study, care was taken to ensure that nicotine/ cotinine serum levels were consistent with those reported for smokers. Blood samples were collected at 15 minutes, and hourly ( 1 to 8 hours) after the first nicotine injection of the day, on the first and last days of drug administration. The first and last days were chosen in order to evaluate whether two injections of $2 \mathrm{mg} / \mathrm{kg}$ of nicotine would reach blood levels of nicotine in the range of those of smokers and whether there would be any cumulative effect during the whole experimental period. Although an initial high nicotine concentration was obtained (15 minutes to 4 hours), data analysis demonstrat-

\section{REFERENCES}

1. Daftari TK, Whitesides TE Jr, Heller JG, Goodrich AC, McCarey BE, Hutton WC. Nicotine on the revascularization of bone graft. An experimental study in rabbits. Spine 1994;19:904-11.

2. Fang MA, Frost PJ, Iida-Klein A, Hahn TJ. Effects of nicotine on cellular function in UMR 106-01 osteoblast-like cells. Bone 1991;12:283-6.

3. Ginnopoulou C, Geinoz A, Cimasoni G. Effects of nicotine on periodontal ligament fibroblasts in vitro. J Clin Periodontol 1999;26:49-55.

4. Hollinger JO, Schmitt JM, Hwang K, Soleymani P, Buck D. Impact of nicotine on bone healing. J Biomed Mater Res 1999;45:294-301.

5. Hollinger JO, Wong MEK. The integrated processes of hard tissue regeneration with special emphasis on fracture healing. Oral Surg Oral Med Oral Pathol 1996;82:594-606.

6. Hopper JL, Seeman E. The bone density in female twins discordant for tobacco use. N Engl J Med 1994;330:38792.

7. Isaac PF, Rand MJ. Blood levels of nicotine and physiological effects after inhalation of tobacco smoke. Eur J Pharmacol 1969;8:269-83.

8. Iwaniec UT, Fung YK, Cullen DM, Akhter MP, Haven MC, Schmid M. Effects of nicotine on bone and calciotropic hormones in growing female rats. Calcif Tissue Int 2000;67:6874 .

9. Jones J, Triplett R. The relationship between cigarette smoking to impaired intraoral wound healing: a review of evidence and implications for patient care. J Oral Maxillofac Surg 1992;50:237-9.

10. Lau GC, Luck JV Jr, Marshall GJ, Griffith G. The effect of cigarette smoking on fracture healing: an animal model. Clin Res 1989;37:A132.

11. Nakajima M, Yamamoto T, Kuroiwa Y, Yokoi T. Improved highly sensitive method for determination of nicotine and cotinine in human plasma by high-performance liquid chromatography. J Chromatogr 2000;742:211-5. ed that nicotine serum levels in the present study remained within the range reported for smokers. Furthermore, despite the long experimental period used, blood level of nicotine was observed to be similar on the first and last days of the experiment; and therefore, a cumulative effect of daily injections was not observed.

In conclusion, within the limits of this study, nicotine affected but did not prevent bone healing in surgically created alveolar ridge defects left to heal spontaneously in dogs. However, the mechanisms and clinical relevance of our findings remain to be further investigated.

\section{ACKNOWLEDGMENTS}

This study was supported by the State of São Paulo Research Foundation (Grants \# 01/06481-3 and 01/06480-7).

12. Peacock ME, Sutherland DE, Schuster GS, Brenna WA, O'Neal RB, Strong SL, et al. The effect of nicotine on reproduction and attachment of human gingival fibroblasts in vitro. J Periodontol 1993;64:658-65.

13. Ramp WK, Lenz LG, Galvin RJS. Nicotine inhibits collagen synthesis and alkaline phosphatase activity, but stimulates DNA synthesis in osteoblast-like cells. Proc Soc Exp Biol Med 1991;197:36-43.

14. Rapuri PB, Gallacher JC, Balhorn KE, Ryschon KL. Smoking and bone metabolism in elderly women. Bone 2000;27:429-36.

15. Ray RD. Vascularization of bone grafts and implants. Clin Orthop 1972;87:43-8.

16. Riebel G, Boden S, Whitesides T, Hutton W. The effect of nicotine on incorporation of cancellous bone graft in an animal model. Spine 1995;20:2198-202.

17. Ruskin JD, Hardwick R, Buser D, Dahlin C, Schenk RK. Alveolar ridge repair in a canine model using rhTGF$\beta 1$ with barrier membranes. Clin Oral Implants Res 2000;11:107-15.

18. Schenk RK, Buser D, Hardwick WR, Dahlin C. Healing pattern of bone regeneration in membrane-protected defects: a histologic study in the canine mandible. Int J Oral Maxillofac Implants 1994;9:13-29.

19. Sopori ML, Kozak W. Immunomodulatory effects of cigarette smoke. J Neuroimmunol 1998;83:148-56.

20. Theiss SM, Boden SD, Hair G, Titus L, Morone MA, Ugbo $J$. The effect of nicotine on gene expression during spine fusion. Spine 2000;25:2588-94.

21. Tripton DA, Dabbous MK. Effects of nicotine on proliferation and extracellular matrix production of human gingival fibroblasts in vitro. J Periodontol 1995;66:105664.
Received for publication on Jul 26, 2004

Sent for alterations on Sep 14, 2004 Accepted for publication on Sep 30, 2004 